\title{
Representation of Feminism in the Novel Jatisaba
}

\author{
Santi Gusfitasari \\ IAIN Bengkulu \\ santigusfita08@gmail.com \\ Dr. Mindani, M. Ag. \\ IAIN Bengkulu \\ mindani70@gmail.com \\ Bustomi, S.Ag., M. Pd. \\ IAIN Bengkulu \\ bustomi.hasan@iainbengkulu.ac.id
}

\begin{abstract}
Background of the problem raised in this research was how the form of feminism and the role of feminism in the novel Jatisaba by Ramadya Akmal. The purpose of this study was to find out how the form of feminism and the role of feminism in the novel Jatisaba by Ramadya Akmal. The method used in this research was descriptive qualitative method, and the approach used in this research was the literary criticism approach of feminism. The data source was the novel Jatisaba by Rmadya Akmal. The data collected in the form of words and quotes. Data collection techniques was in the form of library techniques. The data validity technique was focused on trust testing which consists of two activities, namely increasing persistence and using reference materials. The data analysis technique used the Miles and Huberman analysis model. The results of this study were that the form of feminism and the role of feminism found in the novel Jatiaba by Ramadya Akmal, which was in the form of feminism in the novel, told about a village called Jatisaba, the majority of the population of this village are Indonesian Labor, many Indonesian labor brokers enter the village, one of which was Mae. Many villagers had been victims of violence during their time as migrant workers, both physical and non-physical. The researcher could conclude that women in Jatisaba village experience a lot of physical and non-physical violence. Mae and other Indonesian labor brokers only took advantage of the existing conditions in the village.
\end{abstract}

Keywords: Jatisaba Novel, Feminism, Gender

\section{A. Introduction}

Novel is one of the literary works that are in great demand by readers, not only romantic stories but about struggles, there are still many who are interested in reading them, including stories about women's emancipation, where readers are curious about how women lived in the past. It's not just 
ancient stories that talk about the women's movement, but nowadays there are still works about the struggles of the women's movement/feminism. One of the works that talks about feminism is Jatisaba. Literature is a picture of human life, and is someone's invention. Where the author uses imagination and sometimes from the social life of the community. An author criticizes through a literary work. Literary works of various kinds are not only novels, but there are many other types of literary works. In literary works, the author is free to express his ideas to create a work. Sometimes the author takes personal experience in writing novels.

Novel is a prose fiction story with a certain length that depicts imaginative characters, movements and life scenes. Novel as a work that has intrinsic and extrinsic elements (Iit Kurnia, 2013: 3). So the novel is a literary work with a long duration and has intrinsic and extrinsic elements in it. There are many kinds of novels, some are romance, etc. In literature, there is a lot that raises about feminism, where gender equality is disputed. In feminism, there are many differences between male and female gender, male gender is more dominant than female gender. Feminism is a form of gender inequality for women, both in the family and society. Feminism is a field for women to equalize rights with men's gender.

Jatisaba is one of the works that raises about feminism in a literary work where the main character wants to elevate the status of women and wants gender equality with men and the main character also dominates his own body. In this novel, the main character is more dominant in herself than the other female characters. In this study, the author wants to convey that women and men have gender equality and have the same rights as men.

In this study, researchers are interested in examining the representation of feminism that is lifted from fighting traditional values, and the other side of people's lives. In the case of feminism, many women are not respected and women are considered weak by the male gender, so in this study of feminism 
approach women want to ask for equal rights with men and not different from men's gender.

In this literary work entitled Jatisaba, the researcher is interested in researching and studying more deeply and raising the problems that exist in this novel by Ramadya Akmal, as told by the author. That women experience a lot of physical, non-physical and sexual violence, and Ramadya Akmal also told that women in the village besides experiencing violence also have to work to support their families because of economic demands that urge them to choose to work as migrant workers.

In his work, it is very clearly described by the author how difficult life in Jatisaba village is, so that the residents are very easily influenced by only the lure of money. In this study, researchers are quite interested in the story written by Ramdya Akmal who raises about how life in the village of Jatisaba is. Feminism is a women's movement to get equal rights between men and women in certain fields. This movement is to fight for the rights of women in the eyes of society. (Andrian Risqi Hidayat, et al, 2013: 2) So it can be concluded that feminism is a women's movement. Sometimes society's perception of women is very low, especially men, he thinks that women can't do anything without men, when women have positions above men, women are only considered by men.

This feminist approach is still widely found in today's society, because there is still a lot of violence against women, both physical and non-physical. In society when women have more abilities than the opposite sex, then the woman's existence is only recognized by the community and the opposite sex, but when women do not have more or no more abilities than men, the existence of these women is less recognized by the surrounding community and men.

But in this novel, not all women want to be oppressed by men, there are also those who fight against women's oppression. In this Jatisaba novel, women are more dominantly explained by the author, because the author wants to explain that women also have the same rights as men and women can also have power and have the same positions as men. However, this novel also explains 
that the basis of the oppression of women is that they still experience physical, mental and sexual violence. The novel Jatisaba by Ramadya Akmal is not only read, but researchers are interested in examining the problems contained in this novel, especially about the lives of women in the village.

\section{B. Research Method}

This research was a type of qualitative literary research. Literature research is research that wants to solve theoretical research problems. This research usually uses historical, philosophical, semiotic, philological, and literary approaches. This research was a descriptive qualitative type of research, which is research that describes a symptom, event, event that is happening now. (Heni Friantary, et al, 2020) This is in accordance with the definition of qualitative research, namely a study that produces descriptive data in the form of written words or phrases. from people and from observable behavior.

This study used a literature review technique, which is done by completing and reading literature as materials and writing guidelines in reviewing research. The material was used as a reference for the author in identifying and describing the research problem. The data to complete this research were obtained from various available information sources, such as books and the internet (Freeth, C. A , 2018: 35).

The focus of this research was the representation of feminism in the novel Jatisaba by Ramadya Akmal, which uses a feminine approach. In data collection techniques, the researcher used several methods commonly used in scientific research, namely library research techniques. The data analysis technique used the opinion of Miles and Huberman, namely the stages of data collection, data reduction, data presentation, and drawing conclusions.

\section{Result and Discussion}

\section{Result}

The data obtained after the researchers conducted research, namely knowing how the form of representation in the novel Jatisaba and knowing 
the role of feminism in the novel Jatisaba by Ramadya Akmal. In this case, the researcher uses a feminist literary criticism approach, where one of the media for cultural and social representation describes gender relations. A feminist literary critique helps the study of gender as represented in a literary work (Alpian Rokhmansyah, 2016:63).

a. The Form of Feminism Representation in the Jatisaba Novel In this Jatisaba novel, there are several sections that contain elements of feminism in the story. The author tells about the condition of a village that is still far from being able to afford it and the majority of the people there are trying their luck to become imigrant worker. As in the data below.

\section{Data 01}

"But, your village is one of the biggest foreign exchange suppliers in this district. That's commendable." The man said while taking off his hat (Ramadya Akmal, 2017: 7).

The data above explains that in his village many residents are migrant workers so that the village is the largest foreign exchange supplier.

\section{Data 02}

"Simply put, I take care of the trips of people who want to work abroad or out of town." (Ramadya Akmal, 2017: 27)

" Imigrant worker sclaper, aren't you?," said Jom with an annoying boss attitude"

The quote above begins with the meeting between Jom and Mea who had not seen each other for a long time and Mea greet first and a conversation occured, as in Data 02 describing how their meeting was, even though Mea is a woman but she can also work to earn money not only by depending on man.

\section{Data 03}

"Could you be against me? I grew up here, Jomi, this is my village," I answered briefly. "But there are always negotiations, I 
still want to take them. I sleep at the site. Maybe you can visit me," I continued as I got up from my seat." (Ramadya Akmal, 2017: 28)

The quote above can be concluded that between women and men can carry out negotiations to discuss certain matters concerning work and others.

\section{Data 04}

"Come on you guys up there," I ordered crossing them the road ahead." Later, we will both wait for the car on the dyke," I continued. They nodded." (Ramadya Akmal, 2017: 2)

This data shows women who are leading a group to get to where they are going. And also in the next conversation they got into trouble, the road they were taking was with the police so they decided to take a shortcut.

\section{Data 05}

"Thank God, many children here have gone to school, yes," I said softly.

"I used to go to school too, Mae. Although I did not pass!" replied Sitas rather curtly. I forgot, he's a Dulbur breed. Must be sensitive. (Ramadya Akmal, 2017: 25)

This data explains that many women in Jatisaba village have gone to school like boys, although sometimes some drop out of school due to family circumstances.

\section{Data 06}

"Well, that means, I have to give them special facilities and services so that they believe in me and I just have to say, all these conveniences and privileges come from you, good skipper Jompro. Isn't it?"

“Hehehe, you know what I mean.” (Ramadya Akmal, 2017: 35)

From the quote above, there was a negotiation between Mea and the skipper Jompro regarding their respective desires that would benefit both 
parties, from the results of the negotiations Mea had easy access to dispatch prospective migrant workers who would depart.

b. Finding out the Role of Feminism in the Novel Jatisaba

The role of feminism in the novel Jatisaba is found in the characters in the novel which can be seen in the quote below.

\section{Data 07}

"Remember, you are leaving for the sake of your family. Trust their fate and safety, to..." I couldn't continue with that sentence God didn't play any part in my bad luck. He doesn't deserve to be scapegoated." (Ramadya Akmal, 2017: 2)

From the data, it can be interpreted that the character played a role in the action because the character acted as a broker for migrant workers and mobilized the residents of Jatisaba to try their luck. From the data above, it can be concluded that feminism plays a role in every character wanting to attract their prey to become migrant workers.

\section{Data 08}

"But, my return was purposeful, Jom. Apart from homesickness of course. Lost house. I hope tomorrow can bring some people. I've got some good chances for them there," I said very quietly. (Ramadya Akmal, 2017: 28)

From this data, it can be seen that Mae's return is aimed at bringing residents in Jatisaba to become Indonesian migrant workers abroad with the lure of a lot of money. They do not realize that Mae is an illegal imigrant worker broker who is not guaranteed anything by the government if there is a problem when they work abroad. Mae said that their company is a legal company and has an official permit from the government.

\section{Data 09}


"You need people's trust to make him want to leave Mea. Living in poverty leaves them with no other choice." (Ramadya Akmal, 2017: 35)

The text excerpt explains that Mae must be able to gain sympathy from local residents so that Mae can easily influence people to become migrant worker. However, it is not easy for Mae, because Mae comes from that village and many childhood memories make her a dilemma plus the shadow of past love that always haunts her.

\section{Data 10}

"Of course, this is a satisfactory payment Jom," I replied, pointing to the gold chain necklace hanging in my left hand. I took it from Jom's neck when he had an orgasm." (Ramadya Akmal, 2017: 37)

The data is very clear that the woman is very influential on her body and she does not want to lose the opportunity to get something. Let's necklace is also a payment for the agreement they made together and made each other mutually beneficial.

\section{Discussion}

The novel Jatisaba is one of the works of the nation's children, namely Ramadya Akmal which was published by PT Gramedia in 2017. Feminism is one of the women's movements for gender equality, feminism is a women's movement that demands emancipation or equality and justice for men's rights. (Alfian Rokhmansyah, 2016:37) with the women's emancipation movement, women can feel how life is now, can go to school, etc.

In this Jatisaba novel, the author describes clearly how life is in Jatisaba village. Feminism as an understanding that continues to develop into a stream to change social perspectives on gender equality. The commodification of women who continue to be considered inferior requires a new paradigm that elevates the status of women through the side of 
humanism that focuses on the rationality of feminism (Raditiya Gora, 2015:6).

The feminist movement is a women's movement to reject everything that is marginalized, subordinated and demeaned by the dominant culture, both in the political, economic and social fields in general. Feminism as a movement experienced its first victory in 1920 when the United States constitution recognized women's suffrage and the feminist movement suffered a setback when there was an economic depression that hit almost the entire country in 1930 (Tri Ayu Nutrisia Syam, 2013:10-11). Meanwhile, according to the feminist theory of culture, it emphasizes a matriarchal vision: social ideas about the power of women who are concerned with women's relationships and values, not crime in resolving differences, and human problems in life. In the 19th century this impractical view emphasized the matrix theory, namely the mother-law period which anthropologists inspired to have a clear existence. (Holidin \& Soenyono, 2004:96)

\section{Conclusion}

Based on the research that has been done, it can be concluded as follows:

1. The form of feminism in the Jatisaba novel, which is in the form of facts in the novel where there were still many women who experience violence either when they work or they become housewives. Violence against women is not only about physical violence but also non-physical violence.

2. The Role of Feminism in the novel Jatisaba by Ramadya Akmal. Based on the results of this research, feminism acted as a bridge for women to get equal rights, here the figure of Mae was a broker of migrant workers. Mae is a woman who came from Jatisaba village and had also been a victim of the cruelty of the world, she did not want to repeat the same thing to herself so she chooses a path to survive as a migrant worker broker led by 
Major Tua. Mae is in charge of bringing people to go to other countries illegally without official documents from the government.

\section{References}

Akmal, R. (2017). Jatisaba. Jakarta: PT. Gramedia

A, Kurnia, Iit, \& Priyadi Totok. (2013). Kajian Feminisme dalam Novel Secuil Hati Wanita di Teluk Eden Karya Vanny Chrisma W. Jurnal Pendidikan dan Pembelajaran Katulistiwa, 2(7). https://jurnal.untan.ac.id. Diakses 12 Oktober 2020

Hidayat, Risqi, Andrian, \& Anoegrajekti Novita, dkk. (2013). Representasi Perempuan Dalam Novel Supernova-Petir Karya Dwi Lestari: Kajian Feminisme. Skripsi Universitas Jember. http://repository.unej.ac.id. Diakses 1 Januari 2021

Frientary, Heni, Dkk. (2020). Ringkasan Materi Ujian Komfernsif. Bengkulu: IAIN Bengkulu

Freeth, C. A, Representasi Feminisme Dalam video Klip ( Studi Pada video klip Tubuhku otoritasku ), Ilmu Komunikasi, 2018. http://www.semanticsholar.org diakses 1 Januari 2021

Rokhmansyah, A. (2016). Gengantar Gender \& Feminisme Pemahaman Awal Kritik Sastra Feminisme, (Yogyakarta: Penerbit Garudhawaca)

Sugiyono. (2017). Metodologi Penelitian Kuantitatif, Kualitatif, dan R\&D. Bandung: ALFABETA

Susanto. O. (2017). Representasu Feminisme Dalam Filem Spy. Jurnal EKomunikasi, 5(1). https://media.neliti.com. Diakses 01 Januari 2021 
Tri, A.N.S. (2013). Representasi Nilai Feminisme Tokoh Nyai Ontosoroh Dalam Novel Bumi Manusia Karya Pramudya Ananta Toer (Sebuah Analisis Wacana)", Skripsi Jurusan Ilmu KomunikasiFakultas Ilmu Sosial dan Ilmu Polotik Universitas Hasanuddin. http://core.ac.uk. Diakses 01 Januari 2021

Wellek, Renne, \& Austin Warren. (2016). Teori Kesusastraan. Jakarta: PT Gramedia Pustaka Utama

Wiyanti. (2012). Kritik Sastra Feminis Teori dan Aplikasinya dalam sastra Indonesia, Yogyakarta: Penerbit Ombak

Creswell. W, J. (2015). Penelitian Kualitatif \& Desain Riset. Yogyakarta: Pustaka Pelajar

Dina, F., \& Nuryanti, Agus, dkk. (2013). Representasi Idiologi Patriarki Dalam Novel Tanah Tabu Kajian Feminisme Radikal. Jurnal Sastra Indonesia. 2(1). http://journal.unnes.ac.id. Diakses 23 Desember 2020

Gora, R. (2015). Representasi Feminisme Dalam Karya Sastra (Kajian Semiotika Sosial Novel “ Eks Parasit Lajang” Karya Ayu Utami), Jurnal Humaniora Universitas Bima Sarana Informatika, 15(2). https://ejournal.bsi.ac.id. Siakses 01 Januari 2021

Holidin \& Soenyono. (2004). Teori Feminisme Sebuah Refleksi ke Arah Pemahaman. Jakarta: Holindo press 